\title{
Clinical effect of a herbal dentifrice on the control of plaque and gingivitis. A double-blind study
}

\section{Efeito clínico de um dentifrício herbal no controle de placa e gengivite. Estudo duplo-cego}

\author{
Claudio Mendes Pannuti* \\ Joyce Pereira de Mattos** \\ Paula Nini Ranoya** \\ Alberto Martins de Jesus** \\ Roberto Fraga Moreira Lotufo* \\ Giuseppe Alexandre Romito*
}

\begin{abstract}
The aim of this randomized, double-blind clinical trial was to evaluate the effect of the Paradontax dentifrice on the reduction of plaque and gingivitis. Subjects were randomly allocated into either the test group ( $\mathrm{n}=15$, Paradontax) or the control group ( $\mathrm{n}=15$, standard dentifrice with fluoride). Plaque levels were measured using the Turesky modification of the Quigley \& Hein Plaque Index (PI), and gingivitis was evaluated with the Gingival Index (GI). Subjects were asked to brush their teeth with the allocated dentifrice, three times a day, for 21 days. There was no significant difference between groups in relation to the PI and GI medians, at baseline and at the end of the 21-day period. There was no significant reduction in PI in either the test or control groups. There was a significant decrease in GI in the test group. The authors concluded that there was no difference between the dentifrices in the reduction of plaque and gingivitis.
\end{abstract}

DESCRIPTORS: Dentifrices; Dental plaque; Gingivitis.

RESUMO: O objetivo deste ensaio clínico aleatório duplo-cego foi avaliar o efeito do dentifrício Paradontax na redução de placa e gengivite. Os sujeitos da pesquisa foram aleatoriamente arrolados em grupo teste ( $\mathrm{n}=15$, Paradontax) e grupo controle ( $\mathrm{n}=15$, dentifrício convencional com flúor). A quantidade de placa foi aferida por meio do Índice de Placa de Quigley \& Hein modificado por Turesky (IP), e o grau de gengivite, pelo Índice Gengival (IG). Os participantes foram orientados a escovar os dentes com o dentifrício três vezes ao dia, por 21 dias. Não houve diferença significativa entre os grupos com relação aos valores medianos de IP e IG no início do estudo e após 21 dias. Não houve redução significativa no IP dos grupos teste e controle. No entanto, houve uma redução significativa no IG no grupo teste. Os resultados levaram à conclusão de que não houve diferença entre os dois dentifrícios com relação à redução de placa e gengivite.

DESCRITORES: Dentifrícios; Placa dentária; Gengivite.

\section{INTRODUCTION}

The mechanical removal of supragingival plaque is an effective method of controlling plaque and gingival inflammation ${ }^{3,12}$. However, most subjects lack the compliance and dexterity required for adequate toothbrushing and flossing, and thus, are not able to maintain an adequate standard of gingival health. Consequently, chemical agents can be used as adjuncts to aid plaque control $^{1,10}$.

Toothbrushing with a dentifrice is the most widely practiced form of oral hygiene in most countries $^{9}$. As a consequence toothpastes provide an ideal vehicle for chemical adjuncts. A wide range of chemicals, mainly antimicrobial agents, have been added to dentifrices in order to produce a direct inhibitory effect on plaque formation ${ }^{10,15}$. The efficiency of these agents, such as chlorhexidine and triclosan, has been well documented $^{4,13,23}$.

Interest in natural-based toothpastes has increased recently. Of the various herbal dental products considered, Paradontax (GlaxoSmithKline, Middlesex, United Kingdon), has received great attention. It is composed of sodium bicarbonate, sodium fluoride $(1,400 \mathrm{ppm})$ and herbal ingredients including camomile, echinacea, sage, myrrh, rhatany and peppermint oil. Each individual com-

* PhD in Periodontics; **Undergraduated Students - School of Dentistry, Ibirapuera University. 
Pannuti CM, Mattos JP, Ranoya PN, Jesus AM, Lotufo RFM, Romito GA. Clinical effect of a herbal dentifrice on the control of plaque and gingivitis. A double-blind study. Pesqui Odontol Bras 2003;17(4):314-8.

ponent is reputed to have a variety of medicinal properties.

Camomile has anti-inflammatory properties, and it is supposed to decrease gingival inflammation $^{7}$. Echinacea is claimed to stimulate the immune response and to activate leukocytes. Sage is reputed to decrease tissue bleeding and myrrh is a natural anti-septic ${ }^{18}$. The medicinal properties of peppermint oil are: analgesic, anti-septic, anti-inflammatory and antimicrobial, among others ${ }^{14}$.

Few controlled trials have been found in the literature concerning the efficiency of this herbal toothpaste. Some studies reported that Paradontax was able to produce a significant decrease in plaque and gingivitis, as compared to a control dentifrice ${ }^{21,22}$, while others found no significant advantage over a standard toothpaste ${ }^{14,17}$. Given the differences in the results of these trials and the relative paucity of data regarding the product in Brazil, the aim of this study was to evaluate the efficacy of the Paradontax dentifrice in the control of plaque and gingivitis.

\section{MATERIAL AND METHODS}

Thirty-one dental students from a dental school, aged from 18 to 35 years, took part in this double-blind, parallel, randomized controlled trial. The participants were randomly assigned to either the experimental group ( $\mathrm{n}=16$ ) or the control group $(n=15)$. There was one withdrawal from the trial (one subject from the test group, at week 3), thus, 30 volunteers completed the trial. The experimental group used the herbal dentifrice (Paradontax) and the control group used a dentifrice containing sodium bicarbonate and sodium fluoride $(1,500 \mathrm{ppm})$, with colour and taste similar to those of the experimental dentifrice.

The study subjects were enrolled in the study if they met the following inclusion criteria: had signed the informed consent form, used no orthodontic appliances, had no advanced periodontal disease $^{2}$ (CPITN $=3$ or 4 ), and had undergone no antibiotic therapy one month prior to the study. No volunteers were smokers. Since the study subjects were dental students, no volunteer could participate the study if he or she was taking the subject of periodontics, so that there would be no conflict of interest in the form of grade alteration or other forms of incentives or repression.

All participants received an adult-sized, softbristled toothbrush, and were instructed to brush their teeth for one minute three times a day, using the Bass technique, and to refrain from any other oral hygiene procedures, including mouthwashes, throughout the duration of the study. They were also instructed to use the assigned dentifrice for 3 weeks.

The study protocol was approved by the University's Ethics Committee (Report COEPE/UNib n. 01/02). All volunteers were asked to read the informed consent form, and to sign it if they agreed as to its contents.

The participants were examined for plaque and gingivitis at baseline and after 3 weeks. One of the examiners disclosed and scored supragingival plaque according to the Turesky et al. ${ }^{20}$ (1970) modification of the Quigley, Hein ${ }^{16}$ (1962) Plaque Index (PI). Another examiner scored gingivitis according to the Gingival Index ${ }^{11}$ (GI). Each tooth was scored at 4 sites: mesiofacial, midfacial, distofacial and midlingual. All teeth were examined, except for third molars. All participants received prophylaxis after clinical examination. Both examiners were previously calibrated. Intra-examiner agreement for PI and GI was evaluated by repeated measurements on 10 patients, with at least a one hour interval $^{5}$. The agreement between the two examinations was calculated by means of the weighted Kappa coefficient: 0.76 for PI and 0.74 for GI. After 3 weeks, the subjects were re-examined by the same investigators, and were asked to return their dentifrice tubes, so that compliance could be evaluated. On all examinations, the examiner visually inspected the hard and soft oral tissues for the presence of any adverse reaction. On the examination at the end of the 3-week period, the volunteers were also asked to report if they experienced any unusual reaction.

A whole-mouth mean score was obtained for each participant, by averaging the values from all scored dental surfaces in the subjects of both groups.

The normality of the distribution of variables was verified using the Kolmogorov-Smirnov Goodness of Fit test. Homogeneity of variances was analysed using the Levene test. The mean scores of PI and GI were compared between the test and control groups by means of the Mann-Whitney test. In each group, the mean scores of PI and GI were compared between baseline and the end of the trial (21 days), by means of the Wilcoxon test. 
Pannuti CM, Mattos JP, Ranoya PN, Jesus AM, Lotufo RFM, Romito GA. Clinical effect of a herbal dentifrice on the control of plaque and gingivitis. A double-blind study. Pesqui Odontol Bras 2003;17(4):314-8.

TABLE 1 - Background characteristics of patients in the test and control groups.

\begin{tabular}{l|c|c|c|c|c}
\hline \hline \multirow{2}{*}{} & \multicolumn{2}{|c|}{ Test } & \multicolumn{2}{c|}{ Control } & \multirow{2}{*}{$\mathrm{p}^{*}$} \\
\cline { 2 - 5 } & $\mathrm{n}(\%)$ & $\begin{array}{c}\text { Mean } \\
\left(\mathrm{SD}^{\dagger}\right)\end{array}$ & $\mathrm{n}(\%)$ & $\begin{array}{c}\text { Mean } \\
\left(\mathrm{SD}^{\dagger}\right)\end{array}$ & \\
\hline $\begin{array}{c}\text { Age } \\
\text { (years) }\end{array}$ & $\begin{array}{c}15 \\
(100.0)\end{array}$ & $\begin{array}{c}24.9 \\
(4.3)\end{array}$ & $\begin{array}{c}15 \\
(100.0)\end{array}$ & $\begin{array}{c}24.4 \\
(2.1)\end{array}$ & \multirow{2}{*}{0.71} \\
\hline \multicolumn{4}{|c|}{ Sex } & \multirow{2}{*}{1.00} \\
\hline Male & $10(66.6)$ & $10(66.6)$ & \\
\hline Female & $5(33.3)$ & $5(33.3)$ & \\
\hline \hline
\end{tabular}

*p-value from $t$-test for age and from chi-square for sex. $\dagger \mathrm{SD}=$ standard deviation.

TABLE 2 - Mean, median, standard deviation and comparison between the test and control groups with regard to the Plaque Index.

\begin{tabular}{|c|c|c|c|c|}
\hline & & $\overline{~ T e s t ~}$ & Control & $\mathrm{p}$ p $\left(\mathrm{MW}^{*}\right)$ \\
\hline \multirow{4}{*}{ Baseline } & Number & 15 & 15 & \multirow{4}{*}{0.96} \\
\hline & Mean & 0.33 & 0.33 & \\
\hline & Median & 0.32 & 0.35 & \\
\hline & $\mathrm{SD}^{\dagger}$ & 0.16 & 0.19 & \\
\hline \multirow{5}{*}{21 days } & Number & 15 & 15 & \multirow{4}{*}{0.48} \\
\hline & Mean & 0.31 & 0.28 & \\
\hline & Median & 0.32 & 0.29 & \\
\hline & $\mathrm{SD}^{\dagger}$ & 0.15 & 0.16 & \\
\hline & $\mathrm{p}\left(\mathrm{W}^{* *}\right)$ & 0.73 & 0.60 & \\
\hline
\end{tabular}

${ }^{*} \mathrm{MW}=\mathrm{p}$-value from Mann-Whitney test; ${ }^{* *} \mathrm{~W}=\mathrm{p}$-value from Wilcoxon test; ${ }^{\dagger} \mathrm{SD}=$ standard deviation.

\section{RESULTS}

The background characteristics of the subjects are shown in Table 1.

Table 2 shows mean, median and standard deviation from the whole mouth averages for the Plaque Index. There was no statistically significant differences between the groups at baseline $(\mathrm{p}=0.96)$ or after 21 days $(\mathrm{p}=0.48)$. There was a pattern for decreasing plaque level in both groups, but there was no significant decrease from baseline to the 21 day period for the test group $(\mathrm{p}=0.73)$ and the control group $(\mathrm{p}=0.60)$.

Table 3 shows the mean, median and standard deviation for the whole mouth averages for the Gingival Index. There was no difference between
TABLE 3 - Mean, median, standard deviation and comparison between the test and control groups with regard to the Gingival Index.

\begin{tabular}{l|l|c|c|c}
\hline \hline \multicolumn{2}{|l|}{} & Test & Control & $\mathrm{p}\left(\mathrm{MW}^{*}\right)$ \\
\hline \multirow{4}{*}{ Baseline } & Number & 15 & 15 & \\
\cline { 2 - 4 } & Mean & 0.10 & 0.10 & \multirow{3}{*}{0.92} \\
\cline { 2 - 4 } & Median & 0.10 & 0.12 & \\
\cline { 2 - 4 } & $\mathrm{SD}^{\dagger}$ & 0.03 & 0.05 & \\
\hline \multirow{4}{*}{ days } & Number & 15 & 15 & \multirow{2}{*}{0.08} \\
\cline { 2 - 4 } & Mean & 0.03 & 0.06 & \\
\cline { 2 - 4 } & Median & 0.03 & 0.06 & \\
\cline { 2 - 4 } & $\mathrm{SD}^{\dagger}$ & 0.02 & 0.05 & \\
\hline & $\mathrm{p}\left(\mathrm{W}^{* *}\right)$ & $<0.001$ & 0.059 & \\
\hline \hline
\end{tabular}

${ }^{*} \mathrm{MW}=\mathrm{p}$-value from Mann-Whitney test; $* * \mathrm{~W}=\mathrm{p}$-value from Wilcoxon test; ${ }^{\dagger} \mathrm{SD}=$ standard deviation.

the groups at baseline $(\mathrm{p}=0.92)$. There was a significant decrease in gingivitis in the test group $(p<0.001)$. The control group showed a decrease in gingivitis, though not statistically significant $(p=0.059)$. There was no evidence of statistically significant treatment differences between the groups after 21 days $(p=0.08)$.

One subject in the test group and three in the control group reported adverse reactions during the trial. The most common adverse reactions were mild ulcerative lesions on the tongue and gingival tissue, burning sensation, tissue sensitivity and dryness of the oral tissues.

\section{DISCUSSION}

In this study, the herbal toothpaste (Paradontax) and the standard dentifrice were not able to reduce plaque significantly. The herbal product provided a significant reduction in gingivitis, but there was no significant difference between the test and control groups at the end of the trial. These results are in agreement with those reported by Saxer et al. ${ }^{17}$ (1995) and Mullaly et al. ${ }^{14}$ (1995), but are in disagreement with the Yankell et al. ${ }^{21}$ (1988) and Yamkell et al..$^{22}$ (1993) investigations.

Home-use toothpaste studies are often influenced by a number of factors which can mask the superiority of a test agent over the controls. One factor that may influence the outcome of these investigations is the Hawthorne effect ${ }^{8}$. Participants in clinical trials may experience some improvement associated not to the therapeutic properties of the test agent but rather related to a behaviour modification, as a consequence of the sheer partic- 
Pannuti CM, Mattos JP, Ranoya PN, Jesus AM, Lotufo RFM, Romito GA. Clinical effect of a herbal dentifrice on the control of plaque and gingivitis. A double-blind study. Pesqui Odontol Bras 2003;17(4):314-8.

ipation in the trial. Subjects participating in oral hygiene studies improve their toothbrushing, irrespective of the product they receive ${ }^{14,15}$. Since the volunteers in this research were dental students, it might be considered that the Hawthorne effect was of particular importance in the results of the experiment.

Besides that it is possible that the experimental period ( 3 weeks) was insufficient to demonstrate the superiority of Paradontax over the control dentifrice. Lack of compliance with the use of the assigned dentifrice can also occur in home-use studies.

In this study, the Turesky et $a .^{20}$ (1970) index was used to assess plaque. This index was chosen because of its sensitivity to detect small deposits of plaque $^{4,15,19}$. However, the cut-off between the scores can be difficult to assess, so calibration of examiners was performed to solve this problem.

For statistical purposes a whole-mouth mean was calculated for each participant by averaging the values from all scored surfaces in the mouth of the subject. Data for PI and GI showed normal distribution by means of the Kolmogorov-Smirnov test, and homogeneity of variances was demonstrated by the Levene test. Nevertheless, the original data belong to an ordinal scale and are not continuous data. Thus, it was decided that non-parametric tests ${ }^{6}$ be used to compare the two groups (Mann-Whitney test), and the same group at different times (Wilcoxon test).

In conclusion, the Paradontax dentifrice presented no significant clinical advantage over the conventional toothpaste with fluoride. Nevertheless, it did produce a decrease in plaque and gingivitis. Even though this product is more expensive than a standard toothpaste, it can be used as an alternative to conventional formulations for individuals with an interest in naturally based products.

\section{REFERENCES}

1. Addy M, Moran J, Wade W. Chemical plaque control in the prevention of gingivitis and periodontitis. In: Lang NP, Karring T. Proceedings of the First European Workshop on Periodontology. London: Quintessence Publishing; 1994. p. 244-57.

2. Ainamo J, Barmes DE, Beagrie G, Cutress T, Martins J. Development of the World Health Organization (WHO) community periodontal index of treatment needs. Int $\mathrm{J}$ Dent Res 1982;32:281-91.

3. Axelsson P, Lindhe J, Nystrom B. Prevention of caries and periodontal disease. Results of a 15-year longitudinal study in adults. J Clin Periodontol 1991;18:182-9.

4. Binney A, Addy M, McKeown S, Everatt L. The choice of controls in toothpaste studies. J Clin Periodontol 1996;23:456-9.

5. Blieden TM, Caton JG, Proskin HM, Stein SH, Wegener CJ. Examiner reliability for an invasive gingival bleeding index. J Clin Periodontol 1992;19:262-7.

6. Bulman JS, Osborne JF. Significance tests. Part 3. Br Dent J 1989;166:218-21.

7. de Rysky S. The effects of officinal herbs on inflammation of the gingival margin: a clinical trial with a newly formulated toothpaste. J Clin Dent 1988;1:22-4.

8. Fletcher RH, Fletcher SW, Wagner EH. Epidemiologia Clinica: elementos essenciais. $3^{\mathrm{a}}$ ed. Porto Alegre: Artes Médicas Sul; 1996.

9. Frandsen A. State of the science review: mechanical oral hygiene practices. In: Löe H, Kleinman DV. Dental plaque control measures and oral hygiene practices. $1^{\text {st }}$ ed. Oxford: IRL Press; 1986. p. 93-116.
10. Kornman KS. The role of supragingival plaque in the prevention and treatment of periodontal disease. J Periodontal Res 1986;21:5-22.

11. Löe H, Silness J. Periodontal disease in pregnancy. Acta Odontol Scand 1963;21:533-51.

12. Löe H, Theilade E, Jensen SB. Experimental gingivitis in man. J Periodontol 1965;36:177-87.

13. Moran J, Addy M, Newcombe RG, Marlow I. A study to assess the plaque inhibitory action of a newly formulated triclosan toothpaste. J Clin Periodontol 2001;28:86-9.

14. Mullaly BH, James JA, Coulter WA, Linden GJ. The efficacy of a herbal based toothpaste on the control of plaque and gingivitis. J Clin Periodontol 1995;22:685-9.

15. Owens J, Addy M, Faulkner J. An 18 week home-use study comparing the oral hygiene and gingival benefits of triclosan and fluoride toothpastes. J Clin Periodontol 1997;24:626-31.

16. Quigley GA, Hein JW. Comparative cleansing efficiency of manual and power brushing. J Am Dent Assoc 1962;25:26-9.

17. Saxer UP, Menghini G. The effect of two toothpastes on plaque and gingival inflammation. $\mathrm{J}$ Clin Dent 1995;6:154-6.

18. Schauenberg P, Paris F. Guide to medicinal plants. $3^{\text {rd }}$ ed London: Lutterworth Press; 1977.

19. Triratana T, Rustogi KN, Volpe AR, DeVizio W, Petrone M, Giniger M. Clinical effect of a new liquid dentifrice containing triclosan/copolymer on existing plaque and gingivitis. J Am Dent Assoc 2002;133:219-25. 
Pannuti CM, Mattos JP, Ranoya PN, Jesus AM, Lotufo RFM, Romito GA. Clinical effect of a herbal dentifrice on the control of plaque and gingivitis. A double-blind study. Pesqui Odontol Bras 2003;17(4):314-8.

20. Turesky S, Gilmore ND, Glickman I. Reduced plaque formation by the chloromethyl analogue of victamine C. J Periodontol 1970;41:41-3.

21. Yankell SL, Emling RC. Two-month evaluation of Paradontax dentifrice. J Clin Dent 1988;1:22-4.
22. Yankell SL, Emling R, Perez B. Six-month evaluation of Paradontax dentifrice compared to a placebo dentifrice. J Clin Dent 1993;4:26-30.

23. Yates R, Jenkins S, Newcombe RG, Wade WG, Moran J, Addy M. A 6-month usage trial of a $1 \%$ chlorhexidine toothpaste. J Clin Periodontol 1993;20:130-8.

Recebido para publicação em 03/02/03 Enviado para reformulação em 23/07/03 Aceito para publicação em 25/09/03

\section{Scientific Electronic Library Online

SciELO - Scientific Electronic Library Online é uma coleção eletrônica de revistas científicas disponíveis na Internet. A coleção traz os textos completos de artigos científicos, bases de dados e relatórios de uso e de impacto da literatura científica publicada no site.

Em operação desde 1997, atualmente estão disponíveis 29 revistas brasileiras nas áreas de ciências biológicas e da saúde, ciências sociais e humanas, ciências agrárias, física etc. Novas publicações são incluídas regularmente em várias especialidades.

Entre as revistas de nossa coleção, está a Pesquisa Odontológica Brasileira.

\section{Consulte a Pesquisa Odontológica Brasileira (Revista de Odontologia da USP) na SciELO - http://wwww.scielo.br/rousp}

